\title{
水溶液からの酸化物ナノ構造材料の合成
}

\author{
出来成人 ${ }^{\mathrm{a}, \mathrm{b}}$, 水 畑 穣 ${ }^{\mathrm{b}}$ \\ ${ }^{\mathrm{a}}$ 山梨大学 燃料電池ナノ材料研究センター ( ⿳ 400-0021 山梨県甲府市宮前町 6-43) \\ b 神戸大学 大学院工学研究科 ( T 657-8501 兵庫県神戸市灘区六甲台町 1-1)
}

\section{Synthesizing Process of Metal Oxides Nanostructured Materials from Aqueous Solutions}

\section{Shigehito DEKI ${ }^{\mathrm{a}, \mathrm{b}}$ and Minoru MIZUHATA ${ }^{\mathrm{b}}$}

\author{
${ }^{a}$ Fuel Cell Nanomaterials Center, University of Yamanashi(6-43, Miyamae-cho, Kofu-shi, Yamanashi 400-0021) \\ ${ }^{\mathrm{b}}$ Graduate Shcool of Engineering, Kobe University(1-1, Rokkodai-cho, Nada-ku, Kobe-shi, Hyogo 657-8501)
}

Keywords : LPD, LPI, Advanced Material, Inorganic Synthesis, Fluorocomplex

\section{1. はじめに}

無機材料とりわけ金属酸化物材料は, 各種機能性材料とし て広く用いられている。エレクトロニクス, 磁性材料, 各種 合成用触媒，エネルギー変換材料，耐熱材料などその用途は 多岐にわたっている。原材料と異なり機能性材料は一般に, その形状は非常に重要で, 用途ならびに利用する機能に依存 して, 様々の形状で用いられる。その上, 用途によりバルク・ セラミックス, 繊維, 薄膜, ナノ粒子などのさまざまな形状 をとり機能を発現する範囲もマクロサイズからミクロ, ナノ サイズと幅広い。また, 状態も単結晶, 多結晶, 非晶質, ガ ラスなどさまざまであり, 局所, 多相, 多層構造, 傾斜組成 を有するなど千差万別であると言えよう。

無機材料の中でも金属酸化物は高融点を有するため耐熱材 料として古くより用いられてきた。金属材料と異なり硬度も 高く, 延性, 展性もそしく, その塑性加工は金属やポリマー と異なり容易ではない。そのため, セラミック技術を用い一 旦粉末として原料合成し, 粉体の焼結を利用して形状化する か, もしくは非晶質化もしくはガラス化し軟化点を利用した 形状化が成されてきた。近年は光学材料の製造にゾルーゲル 法や気相軸付け (VAD) 法のような各種の液体, 気体の前駆体 (プレカーサー)からのバルク材料の合成法も開発されている。

薄膜材料に関しては, 材料の軽薄短小化が強く求められる エレクトロニクス分野において主に活発な実用化の技術開発 がなされ，スパッター, CVD, 蒸着など乾式製膜技術が大 きな進歩を遂げた。エレクトロニクス分野における機能性材 料の薄膜化・微細化への流れの中, 複雑な微細配線や素子の 多層構造の作製に, 液相もしくは気相エッチングによる微細 化プロセス (top-down process, break-down)が用いられてきた。 UV や X 線, 電子線による感光性レジストを用いたリソグラ フィー(マスク・プロセス)の開発で大きく進歩した。一方, 製膜技術も積み上げプロセス (bottom-up process, build-up process）に分類される基板の表面形状に沿って成膜するオ
ン・サーフェス・プロセス (on-surface process)が一般的となっ た。それらのハイブリッド・プロセスも用いられている。例 えば, オン・サーフェス・プロセスである金属めっき法とリ フト・オフ法を巧みに組み合わせたダマシンプロセス (damascene 法) は新しい配線の微細化プロセスとして広く用 いられるようになっている。

現在, 酸化物薄膜の調製には, 主に乾式法に分類されるスッ パター法, CVD, 蒸着法などが用いられているが, 複雑な 表面にも緻密な薄膜を均一に調製する方法として, 近年, 大 きなエネルギーを必要とせず, 環境負荷も少ない溶液を用い るソフトプロセスとして「ソフト溶液プロセス (SSP : Soft Solution Process)」が, 環境・エネルギー問題への関心の高 まりとともに注目を集めるようになってきた。とりわけ，著 者らが開発してきた液相析出法 (LPD：Liquid Phase Deposition) は大面積, 複雑形状表面への析出が可能であることから特徴 ある製膜法として注目されている。著者らは, その発展型で ある液相充填法 (LPI : Liquid Phase Infiltration)を, 金属酸化 物の薄膜もしくはセラミックス様の多結晶ナノ構造体(ナノ セラミックス)を調製法として提案している(図1)。各種基 板またはテンプレートを処理溶液に浸漬させることにより， 溶液内平衡反応を利用して基板上に自己析出 - 成長型の成膜 法で, 湿式セラミックス製造法とも言える手法である。析出 メカニズムは異なるが金属の無電解めっきに類似した成膜法 である。

従来のセラミックスの概念では微細な粉体を焼結して形状 を与えるが，微細形状を従来の焼結法で調製しようとすると， 高温では微細化による融点, 軟化点の低下が生じ, 焼成時に 目的とする微細構造の破壊が生じる。一方, 本法では, 常温 で, かつ水溶液系から穏和な条件で調製するため, 各種テン プレート(型)の利用が可能で, 精度良く微細構造を有する材 料調製が可能になる。著者らは LPD 法・LPI 法により，様々 なスケールの規則構造や単分散な高次構造有するナノ構造セ ラミックスを調製することができることが明らかにしてきた。 


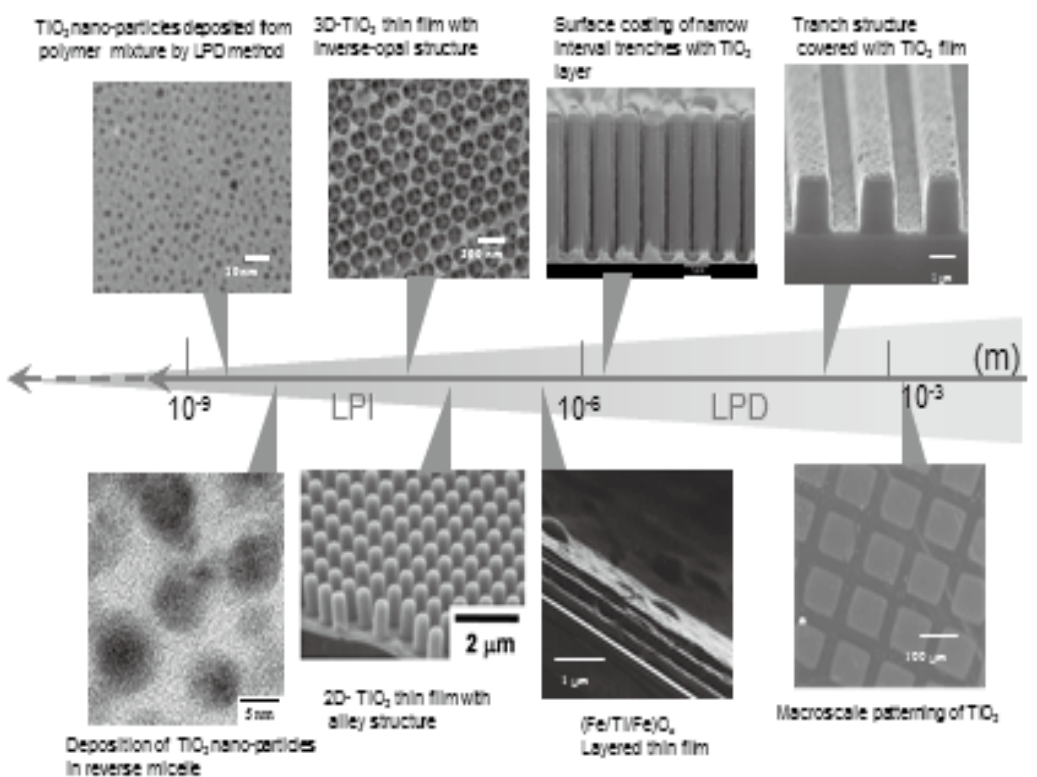

図 1 液相析出法, 液相充填法による析出膜のマルチディメンショナル・スケーリング

また，LPD 法を様々な電子・化学デバイスに適用する手法 について基礎的な観点から研究展開し, 水溶液反応によるセ ラミックス合成での形状と構造制御を目指した。すでに，数 $10 \mathrm{~nm}$ の空間規則性を有するセラミックスの合成法の開発を 試み, 新規デバイスへの応用として, VOC, 水素などのガ スセンサへの適用や, 電気化学材料への適用が試みてきた。 また，分子レベルの微細な形状にも追随性がよく，本手法を 用いて, 日, 米の研究グループは分子インプランテーション (分子鋳型)により生体分子認識によるセンサーへの応用を試 みている。

以下にこれらの手法を用いた具体的な薄膜，ナノ粉体，ナ ノ規則構造などの形状および局所組成を付加した合成方法に ついて概説する。

\section{2. 液相析出法}

上述したように金属酸化物は，より微細なナノレベルの構 造を有することによって, 光学, 半導体, 電子セラミックス など, 様々な分野において重要な量子的機能を発現し, 分子 機能性素子への材料応用が期待されている。しかしながら, その製法については従来の物理的手法が主であり, 精緻な組 成制御を行うことはきわめて困難であるとされている。液相 析出法は他の製膜法と比較して, 反応速度が相対的に遅く, また溶存種の拡散速度と平均自由行程が気相法における反応 種と比較して非常に小さい。また, 溶液という均一場での反 応であるため, 数 $\mathrm{nm}$ オーダの単分散単結晶粒子の調製はじ めポリマー・コロイド結晶のナノ間隙や界面活性剤のミセル 内などの微少空間への析出なども可能であることをすでに見 いだしている。

液相析出法は水溶液中における金属フルオロ錯体の加水分 解平衡反応を利用し, 酸化物薄膜を基板上に直接成長させる 方法である。金属フルオ口錯体は水分子との共存下において 下記(1)式のように平衡状態にある。通常, 金属フッ化物水 溶液の加水分解反応は自発的に進行せず, 水溶液中に平衡状

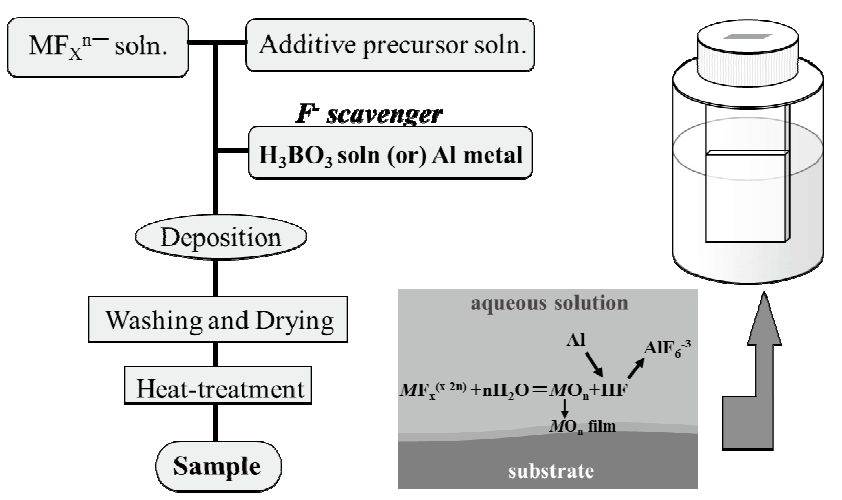

図 2 液相析出法 (LPD 法)による製膜プロセス

態で安定に溶存している。この平衡反応は金属フッ化物錯体 よりもフッ化物錯イオンが安定である $\mathrm{BF}_{4}{ }^{-}, \mathrm{AlF}_{6}{ }^{-}$を生じさ せるホウ酸や金属アルミニウム (フッ素イオン捕捉剂)を添加 することにより，(2) 式の反応が進行し, その結果, よく知 られている質量作用の法則に従い, 遊離フッ化物イオンの活 量低下することにより (1) 式の平衡が右側にシフトする ${ }^{1), 2)}$ 。

析出平衡反応 $\mathrm{MF}_{n}{ }^{(x-2 n)+}+n \mathrm{H}_{2} \mathrm{O}=\mathrm{MO}_{x}+x \mathrm{~F}^{-}+2 n \mathrm{H}^{+} \cdots(1)$

析出駆動反応 $\mathrm{H}_{3} \mathrm{BO}_{3}+4 \mathrm{H}^{+}+4 \mathrm{~F}^{-} \rightarrow \mathrm{HBF}_{4}+3 \mathrm{H}_{2} \mathrm{O} \quad \cdots(2 \mathrm{a})$

$$
\mathrm{Al}+6 \mathrm{H}^{+}+6 \mathrm{~F}^{-}=\mathrm{H}_{3} \mathrm{AlF}_{6}+3 / 2 \mathrm{H}_{2} \quad \cdots(2 \mathrm{~b})
$$

平衡が右側にシフトすることに起因する金属酸化物 $\left(\mathrm{MO}_{\mathrm{x}}\right)$ の析出速度は, 駆動反応の速度に依存するが, 適当なフッ素 イオン捕捉剤の濃度を選択すると, 金属酸化物が過飽和状態 で存在するようになる。

反応溶液に浸漬するだけで薄膜を析出させることができ, 常温常圧下で反応が進行するため, 極めて簡単な装置 (反応 容器のみ)で製膜が可能である。実験室レベルの合成の場合は, 図 2 のようにフッ化物イオンに侵されないポリ容器を反応容 器とし, 基板を懸架するだけでよい。また基板表面で直接成 膜するため, 乾式成膜に見られるシャドゥイング(影による 析出むら)が生じず，いわゆる電気めっきで言われるスロー イングパワーが大きく, 複雑な基板形状表面への追従性にも 
優れている (図 4 参照)。液相析出法により合成可能な金属酸 化物は非常に多岐にわたり，これまでに $\mathrm{SiO}_{2}{ }^{3)}, \mathrm{TiO}_{2}{ }^{4)}$, $\mathrm{V}_{2} \mathrm{O}_{5}\left(\mathrm{VO}_{2}\right)^{5)}, \mathrm{SnO}_{2}{ }^{6), 7)}, \mathrm{MoO}_{3}{ }^{8)}, \mathrm{WO}_{3}$ など ${ }^{9)}$ の他, それら の複合薄膜 ${ }^{10)}$, 金属微粒子含有 $\mathrm{TiO}_{2}{ }^{11)}$ などが合成されている。 この本液相析出法により,すでに種々の表面形状を有する 40 種を越える様々な金属酸化物薄膜の合成法を開発してい る ${ }^{12), 13)}$ 。以下にその典型的合成例を示す。

\section{1 液相析出法による各種薄膜状酸化物の製膜}

ここでは薄膜形状の酸化物の析出法について代表的な系に ついて概説する。

\section{2. $1.1 \mathrm{SiO}_{2}$ 薄膜 $^{3)}$}

アルカリ含有ガラスを長期にわたり使用するとその表面に アルカリ金属化合物が溶出・偏析するため, 表面に $\mathrm{SiO}_{2}$ 膜 でコーティングし, 表面に導電性薄膜をコートする際のアル カリバリアを構築することが必要である。同時に, 被覆によ る透明度の低下を防止することも重要である。液相析出法に よる $\mathrm{SiO}_{2}$ 膜コーティングは, 過去にこの目的のために開発 され, 実用化された。 $\mathrm{H}_{2} \mathrm{SiF}_{6}$ 水溶液にシリカゲルを加え, 過 剩の遊離フッ化物イオンを除き, この水溶液にフッ化物イオ ン補足剤としてホウ酸あるいは金属アルミニウムを添加する。 この水溶液に基板を浸漬することにより, 表面上に $\mathrm{SiO}_{2}$ 薄 膜が形成される。反応温度, 濃度などに依存するが析出速度 は遅く, $30{ }^{\circ} \mathrm{C}$ 付近で $10 \mathrm{~nm} /$ hour 程度である。析出した $\mathrm{SiO}_{2}$ 薄膜は基板に直接形成しており，剥離せず，また薄膜中には 基板からのイオンの浸透はない。得られた薄膜は真空蒸着法 やディップコーティングにより形成される薄膜より緻密であ り, CVDにより形成される $\mathrm{SiO}_{2}$ 薄膜類似の特性を示した。

\section{2. $1.2 \mathrm{TiO}_{2}$ 薄膜 ${ }^{4)}$}

フッ化チタンアンモニウム $\left(\left(\mathrm{NH}_{4}\right)_{2} \mathrm{TiF}_{6}\right)$ 水溶液と $\mathrm{F}^{-}$イオン 捕捉である $\mathrm{H}_{3} \mathrm{BO}_{3}$ を混合し, 所定の濃度に希釈し析出溶液と する。基板を析出溶液に浸漬することにより $\mathrm{TiO}_{2}$ 薄膜が形成 される。図 3 に示すように数 10 時間後, 条件により透明もし くは白濁した薄膜が形成されるが，いずれも基板に対しても 剥離することなく安定で, 厚さに依存する均一な干涉色を示し, 膜厚は均一である。XRD 測定により, アナターゼ型 $\mathrm{TiO}_{2}$ の

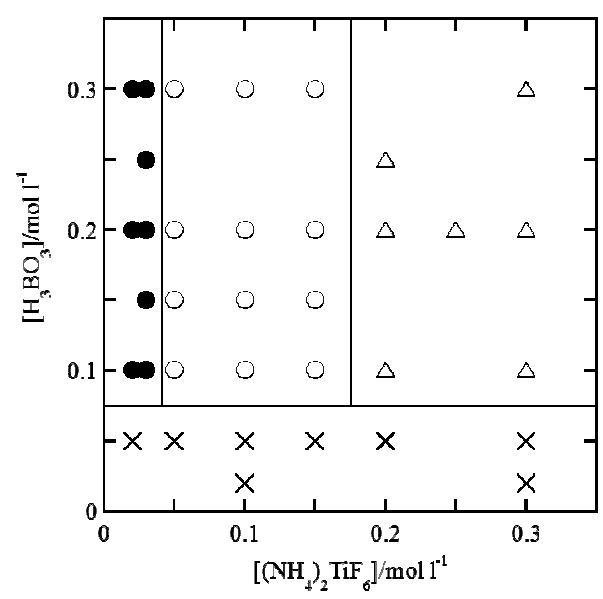

図 $3 \mathrm{LPD}$ 法に扔ける $\mathrm{TiO}_{2}$ 薄膜の合成条件 (濃度条件による析出物の変化)

: $\mathrm{TiO}_{2}$ 白濁膜, $\bigcirc$ : 透明 $\mathrm{TiO}_{2}$ 膜, $\triangle: \mathrm{NH}_{4} \mathrm{TiOF}_{2}, \quad \times:$ 析出せず
多結晶膜が得られた。過剩に $\left(\mathrm{NH}_{4}\right)_{2} \mathrm{TiF}_{6}$ を添加した場合には $\mathrm{NH}_{4} \mathrm{TiOF}_{3}$ の微結晶体からなる薄膜が形成されるが, アナター ゼ型 $\mathrm{TiO}_{2}$ が形成される場合は形成された膜にはフッ素成分が 微量にしか含まれない。このように, 液相析出法によって得 られる $\mathrm{TiO}_{2}$ 薄膜は析出直後においても結晶性である。一方, 得られた薄膜内には析出直後には $\left(\mathrm{NH}_{4}\right)_{2} \mathrm{TiF}_{6}$ に由来する $\mathrm{NH}_{4}$ イオンや吸着水が若干共存する。さらに, $\mathrm{TiO}_{2}$ 薄膜の形成後, 加熱処理を施すことにより, $\mathrm{NH}_{4}$ イオンや吸着水は脱離し, 薄膜に含有される $\mathrm{TiO}_{2}$ の結晶子サイズは $20 \mathrm{~nm}$ 程度まで成長 する。最近, 鉄鋼材料の防蝕被膜としての機能が環境面から 注目されている ${ }^{14)}$

\section{2. $1.3 \beta$ - $\mathrm{FeOOH}$ および $\mathrm{Fe}_{2} \mathrm{O}_{3}$ 薄膜 ${ }^{15)}$}

$\mathrm{Fe}\left(\mathrm{NO}_{3}\right)_{2}$ にアンモニア水を添加し, 生じた $\beta-\mathrm{FeOOH}$ $\mathrm{NH}_{4} \mathrm{~F}-\mathrm{HF}$ 水溶液に再溶解させた溶液とホウ酸水溶液を混合 したものを溶液として，基板を浸漬することにより橙色透明 の $\beta$ - FeOOH 薄膜が得られる。この $\beta-\mathrm{FeOOH}$ 薄膜は図 4 (a) に示すように, それ自身の結晶性が非常に高いことが特徵で あると同時に, 反応速度が $\mathrm{SiO}_{2}$ や $\mathrm{TiO}_{2}$ よりも大きい。さらに, 多結晶金基板上に $\beta-\mathrm{FeOOH}$ 薄膜を形成させると, 図 $4(\mathrm{~b})$ に 示したように界面付近で基板の結晶格子上にエピタキシャル

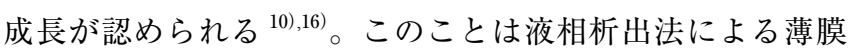
形成が沈殿によるものではなく, 基板表面上における溶存種 の自己析出と膜成長が進行した結果により薄膜が形成するこ とがわかる。このことが液相析出法による析出薄膜の高い緻 密性をもたらす。この析出薄膜を空気中にて焼成すると, ア モルファス状態を経て結晶性の $\gamma-\mathrm{Fe}_{2} \mathrm{O}_{3}$ への転移が生じ, $600^{\circ} \mathrm{C}, 1$ 時間の焼成により赤色の $\gamma-\mathrm{Fe}_{2} \mathrm{O}_{3}$ が得られる。また, 雲囲気調整を行うことにより, $\mathrm{Fe}_{3} \mathrm{O}_{4}, \quad \gamma-\mathrm{Fe}_{2} \mathrm{O}_{3}$ 製膜も可能で ある。

2. 1.4 希土類元素をドープした金属酸化物の製膜 ${ }^{5), 17) ~ 19) ~}$ 機能性材料において希土類元素はしばしば添加され重要な 役割を果たす。希土類イオンは一般的にフッ化物イオンと速 やかに反応し, フッ化物塩として沈殿し反応系外に出る。そ のためフッ化物イオン環境の本法による希土類共存系の製膜 はきわめて困難である。しかしながら, 希土類イオンをキレー 卜化剂でマスクし, 安定な錯体として, 反応期間中溶液中で 共存させることが可能となる。この性質を利用すると $\mathrm{La}^{3+}$, $\mathrm{Eu}^{3+}, \mathrm{Sm}^{3+}, \mathrm{Gd}^{3+}$ などの希土類イオンを含有する複合金属
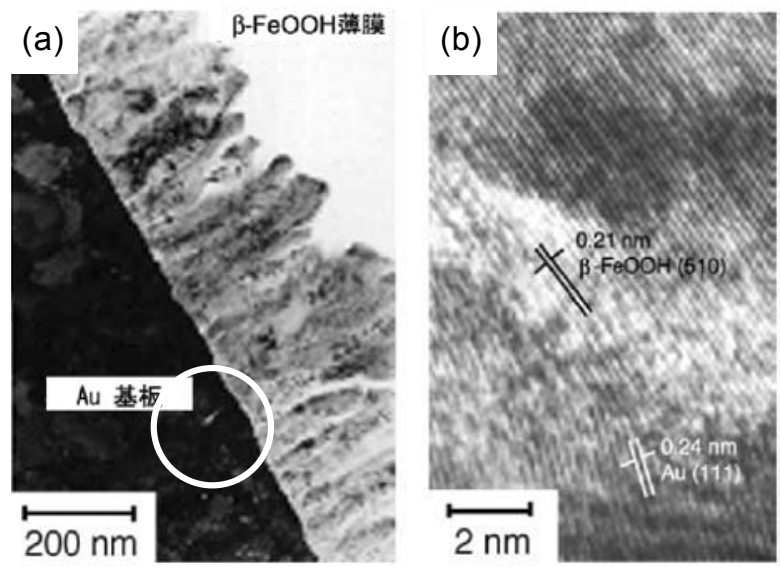

図 $4 \mathrm{Au}$ 基板上への $\beta-\mathrm{FeOOH}$ の析出とエピタキシャル成長 
酸化物薄膜の合成が可能である。希土類イオンを EDTAに て錯化した溶液を反応系に添加することにより $\mathrm{ZrO}_{2}, \mathrm{TiO}_{2}$, $\mathrm{SiO}_{2}$ などの各種酸化物をマトリックスとして所定量の希土 類元素をドープした固体電解質, 蛍光体, 触媒, センサー, 発色体などの機能性薄膜材料の製膜が可能となった ${ }^{17)}$ 。

その他の酸化物薄膜としては二成分混合系の前駆体薄膜を 成膜し, 焼成により所定の構造の薄膜とする物もある。例え ばフェライトやチタン酸バリウムなども工夫により成膜可能 である。他の薄膜の製膜は参考文献を参照されたい ${ }^{13)}$ 。

\section{3. 各種異相構造, ナノ構造を有する酸化物薄膜材料 の製膜}

\section{1 金属ナノ粒子分散薄膜}

反応溶液に微量の貴金属イオンを含有する水溶液を添加す ることにより，金属微粒子分散薄膜の調製が可能である。貴 金属イオンとしては $\mathrm{Au}^{3+}, \mathrm{Pt}^{2+}, \mathrm{Pt}^{4+}, \mathrm{Ag}^{+}$などを共存させ た反応溶液系から析出可能である。析出直後において添加貴 金属元素はイオンとして含有された状態にあり，還元により 金属ナノ粒子とする。この場合, 熱処理によって薄膜内で貴 金属イオンが脱ハロゲンによる自己還元が生じ，金属ナノ粒 子が生成する。塩化金酸を反応溶液に含有させた場合，加熱 により金ナノ粒子が分散した $\mathrm{Au} / \mathrm{TiO}_{2}$ 薄膜が得られる ${ }^{11)}$ 。ま た貴金属源として $\mathrm{H}_{2} \mathrm{PtCl}_{6}$ などを用いることにより $\mathrm{Pt} / \mathrm{TiO}_{2}$

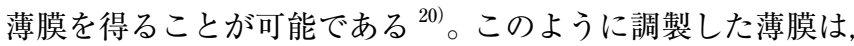
高い光触媒機能を示した。他に $\mathrm{Ag} / \mathrm{TiO}_{2}, \mathrm{Pt} / \mathrm{Nb}_{2} \mathrm{O}_{5}{ }^{21), 22)}, \mathrm{Au} /$ $\mathrm{Nb}_{2} \mathrm{O}_{5}{ }^{23)}$ 膜などが得られている。

\section{2 多層薄膜材料の製膜}

液相析出法による薄膜形成反応を繰り返すことにより，薄 膜の積層化が可能である。例えば, $\left(\mathrm{NH}_{4}\right)_{2} \mathrm{TiF}_{6}$ 水溶液および $\mathrm{H}_{3} \mathrm{BO}_{3}$ 水溶液から $\mathrm{TiO}_{2}$ 薄膜を析出させ, その後, $\beta-\mathrm{FeOOH} /$ $\mathrm{NH}_{4} \mathrm{~F}-\mathrm{HF}$ および $\mathrm{H}_{3} \mathrm{BO}_{3}$ 水溶液から $\beta$ - FeOOH 薄膜を $\mathrm{TiO}_{2}$ 薄膜 上に積層析出させることが可能である ${ }^{10)}$ 。得られた薄膜の 異相界面における $\mathrm{Ti}$ および $\mathrm{Fe}$ 成分の相互拡散は非常に狭い 範囲にとどまっており, 反応溶液を繰り返し交換することに より多層薄膜の形成が可能である。これは，基板形状を選ば ず，密着性の高い薄膜が形成される本法の特徵を活かしたも のである。積層には特に金属酸化物に限らず，高分子層や夕 ンパク質からなる薄膜層の上にも薄膜は形成される。この方 法により $\mathrm{TiO}_{2}$-チトクロム $\mathrm{C}^{24)}$, 有機・無機ハイブリッド 多層膜の合成も可能である ${ }^{25) ~ 27) 。 ~}$

\section{3 傾斜組成薄膜の製膜}

液相析出法における薄膜の成長速度は析出する薄膜組成と その平衡反応に対する駆動反応の速度によりコントロールす ることが可能である。薄膜成長をさせる際に数時間にわたっ て薄膜が形成されることを利用し, 反応槽に反応溶液を流動 させ，さらに添加する反応溶液の組成を連続的に変化させる ことによって，傾斜組成を有する薄膜を形成することが可能 である。気相法によって得られる傾斜組成薄膜は, 薄膜析出 時の反応ガスの組成を連続的な制御は極めて難しい。一方, 液相析出反応においては, 反応速度が穏やかで, 溶液中の溶 存種の平均自由行程が非常に短いため, 溶液内の溶存種の拡 散が十分に行われ，均一組成での薄膜成長である。そのため,
薄膜中の酸化物は成長方向(厚み方向)に対して完全に連続的 な傾斜組成となる。

具体的な $\mathrm{Ti} / \mathrm{Si}$ 系傾斜組成薄膜の製膜例を述べる ${ }^{28)}$ 。 $\left(\mathrm{NH}_{4}\right)_{2} \mathrm{TiF}_{6}$ 水溶液に $\mathrm{H}_{3} \mathrm{BO}_{3}$ 水溶液を加えた $\mathrm{TiO}_{2}$ 反応槽にガラス基板を浸 漬し，その反応槽に一定流量で $\left(\mathrm{NH}_{4}\right){ }_{2} \mathrm{SiF}_{6}$ 水溶液および $\mathrm{H}_{3} \mathrm{BO}_{3}$ 水溶液を所定の割合で添加する。そのため反応槽内の溶液組成 は時間の関数となり, Ti 酸化物から Ti-Si 酸化物共存系となり, 次第に $\mathrm{SiO}_{2}$ となる。形成される薄膜は図 5 に示したように $\mathrm{TiO}_{2}$ から $\mathrm{SiO}_{2}$ へとその組成を連続的に変化させながら析出す る。析出した薄膜を加熱処理した場合でも，その傾斜組成分布 はほとんど変化しない。同様に, Ti/Fe系はじめ種々の系でも 可能である ${ }^{29)}$ 。その数百ナノ以下の膜厚方向の微細な組成傾斜 は, 物性の膜厚方向の連続的変化をもたらし, いわゆる FGM（機 能傾斜材料) 薄膜として, 例えば屈折率の連続傾斜による反射 防止などの新規な機能が期待される。

\section{4 酸化物薄膜の選択析出 (局所成膜)}

薄膜成長の反応初期段階における析出速度について水晶振 動子マイクロバランス $(\mathrm{QCM})$ 法により in-situ で測定した結 果, 薄膜は遊離 $\mathrm{F}^{-}$イオンの消費および結晶核発生に対応し ている一定の誘導期間を経て一定析出速度で析出しており, 時間による膜厚管理が容易であることを示している ${ }^{30)}$ 。

本反応系に特徵的な誘導期間が基板の表面特性に依存する ことを利用して, 局所的な製膜も可能である。例えば，ガラ ス基板上に Pd 金属を局所的に薄くスッパターし，酸化物の 析出を行うと, 誘導時間が短くなり, 選択的に Pd 上に析出 する。誘導時間に大きな差がある基板を用いることにより， 良好な位置選択制を与えることができる ${ }^{31}$ 。（図 1 参照）

\section{4. 液相析出法によるナノ高次構造体の形成 （液相充填法 LPI：Liquid PhaseInfiltration）}

LPD 法による薄膜の析出時においては，平滑な基板材料だ けでなく，形状が非常に複雑な基板，例えば，電子線リソグ ラフィーで作製したナノスケールの微細加工基板, 多孔性粉 体, 繊維などに対して, 非常に高い形状追随性と充填性を示 す ${ }^{32)}$ 。微細加工を施した $\mathrm{Si}$ 基板上に $\mathrm{SiO}_{2}$ 薄膜を液相析出法 により析出させた場合, 図 6 に示したようにパターン形状を 隙間なく被覆することがわかる ${ }^{33)}$ 。同様に $\mathrm{TiO}_{2}$ 薄膜に対し
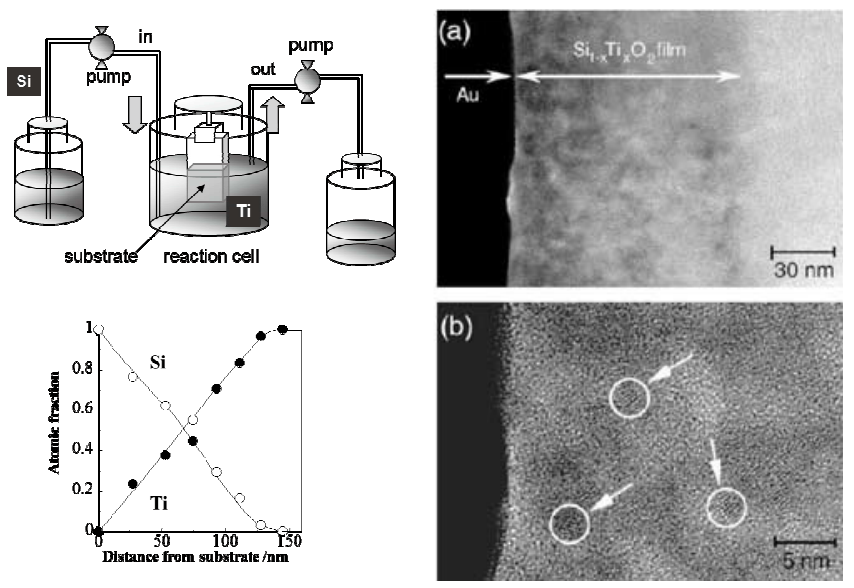

図 5 (a) 金表面に析出した $(\mathrm{Si} / \mathrm{Ti}) \mathrm{O}_{2}$ 薄膜の TEM 断面写真と (b) 微 結晶 (白色囲み) 
ても同様の追従性が得られる。この析出膜を基板より剥離す ることにより，図７に示したように基板上のホール形状が非 常に精度良く転写された状態で高次構造を有する金属酸化物 が得られる ${ }^{8)}$ 。数 $10 \mathrm{~nm}$ 〜数 $\mu \mathrm{m}$ の孔径と間隔を有するナノ ホールアレイを加工したシリコン基板，あるいはシリコン基 板形状を転写したポリマーレプリカフィルムなどを鋳型(テン プレート)として，LPD 法により酸化物の析出を行うと，複 雑な形状を有する微細な酸化物構造体を形成することが可能 であることを示している。図 8 にホールが完全に充填される 反応時間を示した ${ }^{34)}$ 。時間はかかるが数 $100 \mathrm{~nm}$ 径のホール まで入り口での閉塞もなく完全に充填することが可能である。 この方法は，濡れの良い基板の高次構造内に隙間なく反応溶 液が浸透, 拡散し, 金属酸化物が均一に析出, 充填され, 多 結晶ナノ粒子集合体の高次ナノ構造セラミックが構築される。 この手法を用いることにより，図９に示したように種々の形 状制御を行った高次構造セラミックを任意の形状で作製する ことが可能になる。著者らは, CVDの原理を用いた化学気相 充填法 (CVI : Chemical Vapor Infiltration) と同様に，この手法を 液相充填法(LPI 法) として提案し, 研究開発を進めてきた ${ }^{28), 29)}$ 。

金属フルオ口錯体の平衡反応によって成膜する本法では, 初期過程において, 核発生が必要となるが, 適切なフッ素補 足剂の種類と濃度を選択することにより, 溶液バルクでの核 生成が押さえられ，基板表面のみに核発生し，界面上でのみ 反応が進行することになる ${ }^{6)}$ 。これが, 液相析出法における 高い基板追従性と基板への高い密着性の要因の一つであると 推論する。これらの技術を用いることにより, 纎維上に被覆 し，大表面積を有する金属酸化物多孔体を形成することによ

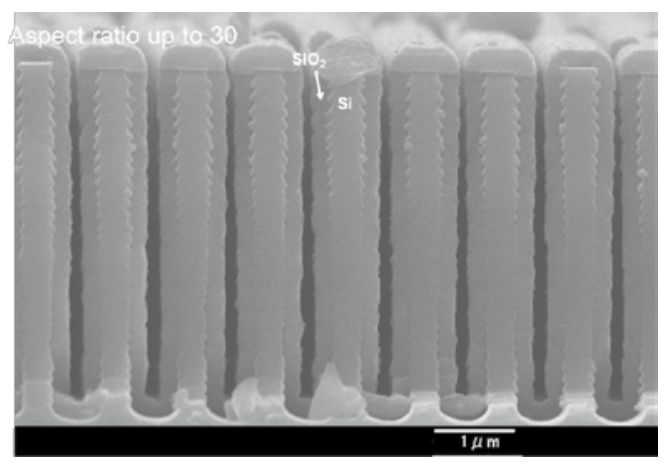

図 6 Deep-RIE で形成した $\mathrm{Si}$ 上に形成した深いトレ ンチへの $\mathrm{SnO}_{2}$ の液相析出 (トレンチ底部, 側 面にも均一に成膜している。)

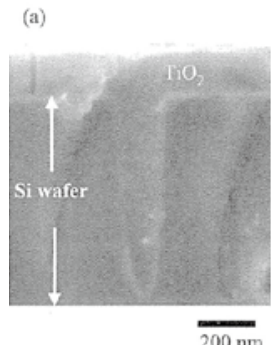

(b)

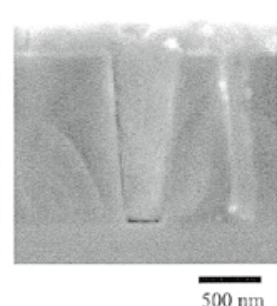

(c)

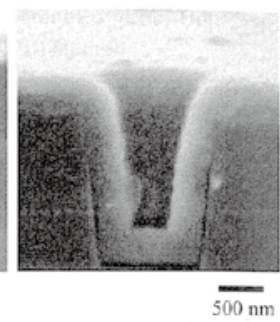

図 7 種々の直径を有するホールへの酸化チタンの充填 (a) $265 \mathrm{~nm}, \quad$ (b) $440 \mathrm{~nm}, \quad$ (c) $1065 \mathrm{~nm}$, 反応時間 : $20 \mathrm{hr}$
り，光利用率が向上し，高い光触媒活性を得ることもできる ${ }^{35)}$ 。 この手法により, 単なる薄膜形状にとどまらず，不均一界面 を用いた自立構造を有する酸化物のナノ構造体の合成も可能 である。その構造制御が容易である利点を生かして新規金属 酸化物ナノ構造体を作製した。液相析出法が, 溶液内平衡反 応による特徵ある反応系であることから，金属フッ化物錯体 の溶液内平衡にも関連する反応機構の解明, すなわち反応中 間体の解明や薄膜結晶構造との相関が明らかになると, 新た な無機溶液反応の解明に繋がると考えらえる。

また材料応用の面から, 特異な電気特性・光学特性などの 機能制御も期待される。数 $10 \mathrm{~nm}$ ～数 $\mu \mathrm{m}$ の孔径と間隔を有 するナノホールアレイを構築したシリコン基板をテンプレー トにするか, もしくは, 溶液反応である低温反応の特性を活 かし，これを母型として，耐熱性がそしいが転写特性に優れ ている酢酸セルロースなどのポリマーレプリカ上に酸化物薄 膜を形成することができる。図 10 のように基板上のホール 形状が非常に精度良く転写された高次構造を有する金属酸化 物が得られる。この手法を用いるナノインプリント法により， 一度電子ビームなどのリソグラフィーで母型を作製し， ポリ マーに転写した基板を用いることにより，表面形状の設計を 行った高次構造セラミックを任意の形状で安価に大量に作製 することが可能になる(図 11 参照)。この方法は液相の高次 構造内に微少空間までも隙間なく反応溶液が浸透, 拡散し, 金属酸化物が析出し，充填される。得られる金属酸化物には 特に制限はなく, また上述の液相析出法により成膜可能な傾 斜組成膜, 分散膜, 多層膜などの種々の析出法とのハイブリッ

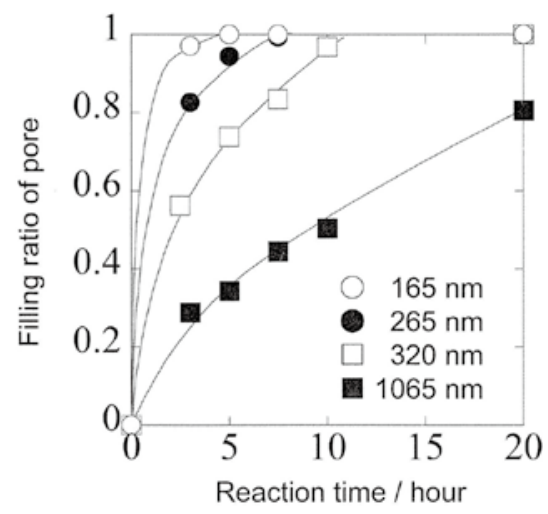

図 8 酸化チタンの充填比と反応時間の関係

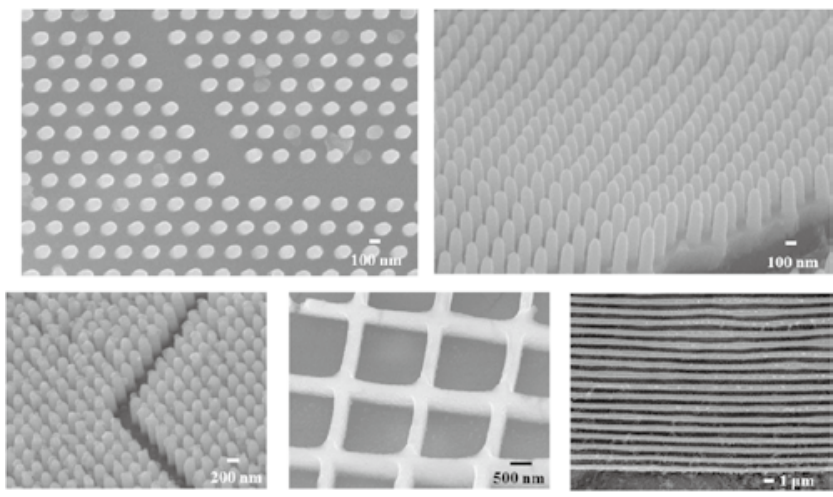

図 9 液相充填法による $\mathrm{TiO}_{2}$ ナノ構造体 
ド化も可能で，表面より中心部に渡り傾斜組成を有するナノ 構造体, 金属ナノ粒子分散酸化物などいずれも形状を付与し ての合成が可能である(図 10, 図 11)。

100 ～ $500 \mathrm{~nm}$ を有するポリスチレン単分散粒子が自己集 積し，コロイド結晶を形成することが知られており，そのホ トニクスクリスタルとしての利用が提案されている。これを テンプレートとして用い，その間隙に LPD 法による緻密な 各種金属酸化物が析出可能であることを示した。液相充填後, テンプレートを熱処理もしくは溶媒により溶解除去を行うこ とによって，3 次元周期性を有する反転オパール構造を有す る酸化物セラミックスを合成した ${ }^{36)}$ (図 10, 図 12 参照)。得 られたセラミックス構造体は, 高い反応性や光学特性を示す ことを見いだした。また，得られた酸化物骨格の反転オパー ルの空孔に異なる酸化物を液相充填することも可能で，任意 の, 機能性が異なる異相構造の構築が可能となる ${ }^{37)}$ 。屈折 率の異なる酸化物を用いると粒径により，より明確なストッ プバンドが出現し, 次世代光学材料への応用も期待される。 また上述の希土類ドープの酸化物を充填することにより角度 依存を示す蛍光体も作製可能である。

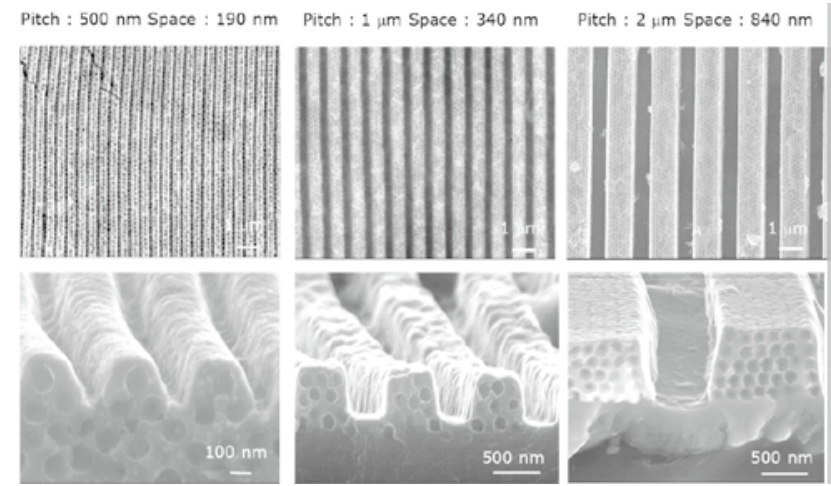

図 10 液相充填法を用いた空孔を内在する規則トレンチ構造体 $\left(\mathrm{SnO}_{2}\right)$

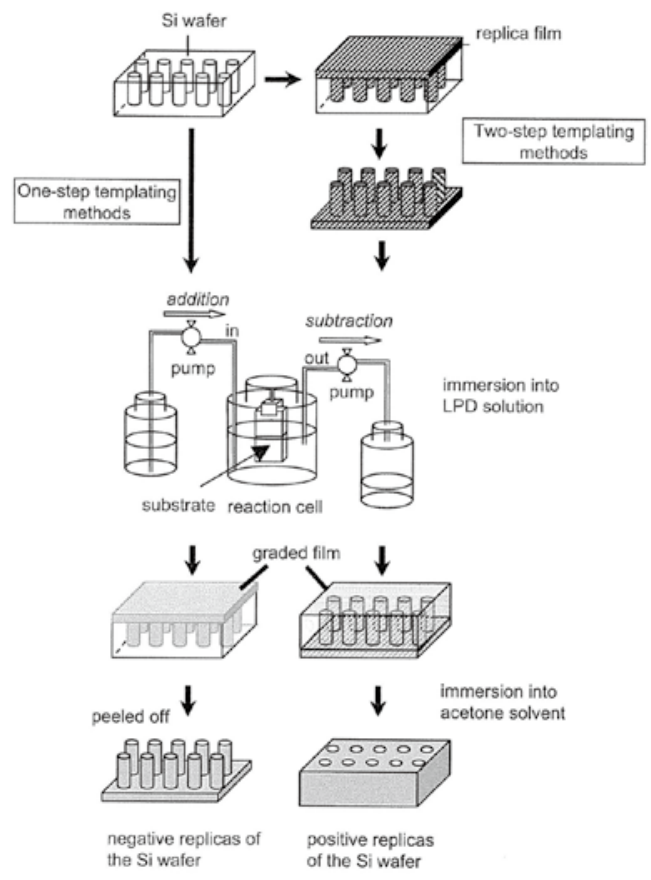

図 11 LPI/ 組成傾斜ハイブリッド薄膜調製法
また，感光性樹脂を用いてリソグラフィーで形成した高分 子基板の表面に液相析出し, 酸化物で覆った後樹脂を除去す ることによりトンネル構造のような空間を付与することも可 能である ${ }^{32)}$

\section{5. ナノプールを用いた酸化物ナノ粒子の合成 ${ }^{38}$}

ナノ制限空間内に束縛された分子・イオン種はバルク場と は異なった振る舞いを示すことが報告されており, ナノ反応 場として化学反応に対する効果を検討することは非常に興味 深い。常温・常圧下にて金属酸化物が析出する液相析出 (以 下 LPD) 法を用いて, 熱力学的に安定な逆相ミセル(以下 $\mathrm{RM})$ ナノプール内での析出状態を調査することにより，ナ ノ制限空間の効果に関して検討を試みた。

エチレンオキサイド(以下 $\mathrm{EO}$ ) ユニットを親水基として有 する非イオン性界面活性剤トリトンX-100 (以下, TX100)お よび油相分散媒として1-ヘキサノール，シクロヘキサンを 混合したものを $\mathrm{RM}$ 溶液とした。前駆体として $\left(\mathrm{NH}_{4}\right)_{2} \mathrm{TiF}_{6}$ お よび $\mathrm{H}_{3} \mathrm{BO}_{3}$ 水溶液を $\mathrm{RM}$ 溶液に均一相になるまで摚拌混合 した後, $30{ }^{\circ} \mathrm{C}$ 一定で所定時間反応させた。また親水基の影 響を検討するために EO ユニットのみで構成されるポリエチ レングリコール (以下 PEG) を LPD 反応液に溶存させ比較検 討した。反応開始数分後より単分散なナノ粒子の形成が観察 され, $\left[\mathrm{H}_{2} \mathrm{O}\right] /[\mathrm{TX} 100]$ 比に従って平均粒子サイズの増大 が確認された。この結果はDLS (動的光散乱)測定から見積 もられた逆ミセルサイズと相関があり, ナノプール内 (ミセ ル内) での局所反応が生じているものと考えられる。また $\mathrm{XRD}$ 測定から水分の減少にともない $\mathrm{TiO}_{2}(\mathrm{~B})$ が優先的に結 晶化することが明らかとなった。PEG 共存系ではバルク反 応場で確認されるアナターゼ型 $\mathrm{TiO}_{2}$ または $\mathrm{NH}_{4} \mathrm{TiOF}_{3}$ 結晶 相が得られた。PEG系のような非制限場と比較してミセル 内の制限場においては，核形成・成長が場の制限を受けるた めに局所的な異相構造を有する結晶相が生成したものと考え られる。同様の結果は $\mathrm{SnO}_{2}$ 系においても確認された ${ }^{7}$ (図 12 参照)。現在このような手法を用いた電池活物質への応用を進 めている ${ }^{39) \sim 43)}$ 。
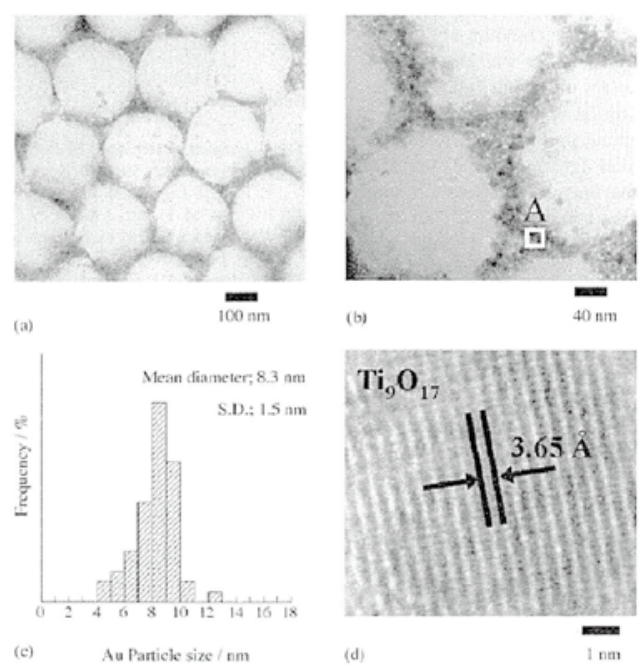

図 $12310 \mathrm{~nm}$ ポリスチレンコロイド結晶を鋳型とした $\mathrm{Au}$ ナノ粒子 / 酸化チタンを骨格とする逆オパール構造の TEM 断面写真 


\section{6.おわりに}

液相析出法は, 溶液中の析出物の堆積による析出ではなく 自己成長型の膜成長をするため，他の製膜法と比較して，高 密度な酸化物薄膜が製膜可能である。この点は LPD 法に固 有の特徵であり，ゾルーゲル法とは明確に区別される。LPI 法はじめ今後組成，形状制御を可能にする製膜法として，そ のマルチスケール性は機能性材料合成手法として高いポテン シャルを有している(図 1)。

今後も LPD 法による成膜のみでなく, 薄膜の機能化に向 けた新たな手法として本法をべースとした改良，改質が可能 であり新規なバージョンも期待される。望まれる機能の具現 にはそれに応じた新しい材料合成プロセスが求められ，才 ン・サイト，オン・サーフェス・プロセスはこれからの無機 合成の重要な分野になると期待される。

(Received January 20, 2012)

\section{文献}

$1)$ M. Mizuhata, Y. Saito, M. Takee, S. Deki ; J.Ceram.Soc.Jpn., 117, (1363), 335 (2009).

2 ) M. Mizuhata, Y. Saito, M. Takagi, S. Deki ; ECS Transactions, 16, (46), 93 (2009).

3 ) H. Nagayama, H. Honda, H. Kawahara ; J. Electrochem. Soc., 135, 2013 (1988)

4 ) S. Deki, Y. Aoi, O. Hiroi, A. Kajinami ; Chem. Lett., 433 (1996).

5 ) S. Deki, Y. Aoi, A. Kajinami ; J. Mater. Sci., 32, 4267 (1997).

6 ) Y. Saito, Y. Sekiguchi, M. Mizuhata, S. Deki ; J. Ceram. Soc. Jpn., 115, (1348), 856 (2007).

7 ) M. Mizuhata, Y. Umekage, A. Nakata, R. Kumaresan, S. Deki ; Chem. Lett., 38, (10), 974 (2009).

8 ) S. Deki, A. B. Béléké, Y. Kotani, M. Mizuhata ; J. Solid State Chem., 182, (9), 2362 (2009).

9 ) S. Deki, A. B. Béléké, Y. Kotani, M. Mizuhata ; Mater. Chem. Phys., 123,614 (2010).

10) S. Deki, N. Yoshida, Hnin Yu YuKo, Y. Aoi, M. Mizuhata, A. Kajinami ; Trans. MRS-J, 24, 109 (1999).

11) S. Deki, Y. Aoi, H. Yanagimoto, K. Ishii, K. Akamatsu, M. Mizuhata, A. Kajinami ; J. Mater. Chem., 6, 1872 (1996).

12）出来成人, 青井芳史; 表面技術, 49, 30 (1998).

13）出来成人, 水畑 穣 ; フッ素化学入門 2010 - 基礎と応用の最前線 「第 5 章 無機フッ素系機能材料 5.2 薄膜生成 - 金属フッ化物錯体 を用いた液相析出法」,p.280，(三共出版, 2010).

14）特願2010-108868

15) S. Deki, Y. Aoi, J. Okibe, H. Yanagimoto, A. Kajinami, M. Mizuhata ; J. Mater. Chem, 7, 1769 (1997)

16) S. Deki, N. Yoshida, Y. Hiroe, K. Akamatsu, M. Mizuhata, A. Kajinami ; Solid State Ionics, 151, 1 (2002).
17) K. Kuratani, M. Mizuhata, A. Kajinami, S. Deki ; Trans. MRS-J, 28, 389 (2003).

18) D. Cho, M. Mizuhata, S. Deki ; J. Ceram. Soc. Jpn., 115, (1346), 608 (2007).

19) A. Nakata, M. Mizuhata, S. Deki ; Electrochim. Acta, 53, (1), 179 (2007).

20) S. Deki, Y. Aoi ; J. Mater. Res., 13, 883 (1998).

21) Hnin Yu YuKo, M. Mizuhata, A. Kajinami, S. Deki ; J. Mater. Chem., 6, $1495(2002)$

22) Hnin Yu YuKo, M. Mizuhata, A. Kajinami, S. Deki ; J. Fluorine Chem., 120, 157 (2003).

23) Hnin Yu YuKo, M. Mizuhata, A. Kajinami, S. Deki ; J. Electroanal. Chem., 559, 91 (2003).

24) N. Kimizuka, M. Tanaka, T. Kunitake ; Chem. Lett., 1333 (1999).

25) S. Deki, Y. Kodama, M. Mizuhata ; ECS Transactions, 16, (25), 73 (2009).

26) S. Deki, Y. Kodama, M. Mizuhata ; J. Ceram. Soc. Jpn., 117, (1363), 326 (2009)

27) L. Li, M. Mizuhata, A. Kajinami, S. Deki ; Synthetic Metals, 146, 17 (2004)

28) S. Deki, S. Iizuka, K. Akamatsu, M. Mizuhata, S. Deki ; J. Mater. Chem. Comm., 11, 984 (2001).

29) S. Iizuka, M. Mizuhata, A. Kajinami, S. Deki ; Trans. MRS-J, 28, 385 (2003).

30) S. Deki, Y. Aoi, Y. Asaoka, A. Kajinami, M. Mizuhata ; J. Mater. Chem., 7, 733 (1997).

31) JP Pat. 4310415

32) M. Mizuhata, T. Miyake, Y. Nomoto, S. Deki ; Microelectro. Eng., 85, (2), 355 (2008).

33) A. J. Niskanen, S. Franssila ; Microelectronic Engineering, 57-58, 629, (2001)

34) S. Deki, S. Iizuka, A. Horie, M. Mizuhata, A. Kajinami ; Chem. Mater, 16, 1747 (2004).

35) H. Kishimoto, K. Takahama, N. Hashimoto, Y. Aoi, S. Deki ; J. Mater. Chem, 8, 1865 (1998).

36) S. Deki, A. Nakata, T. Miyake, S. Ooka, M. Mizuhata ; ECS Transactions, 6, (11), 11 (2007).

37) M. Mizuhata, Y. Kida, S. Deki ; J. Ceram. Soc. Jpn., 115, (1347), 724 (2007)

38) S. Deki, A. Nakata, Y. Sakakibara, M. Mizuhata ; J. Phys. Chem. C, 112, (35), 13535 (2008).

39) S. Deki, A. Hosokawa, A. B. Béléké, M. Mizuhata ; Thin Solid Films, 517, (5), 1546 (2009).

40) A. B. Béléké, A. Hosokawa, M. Mizuhata, S. Deki ; J. Ceram. Soc. Jpn., 117, (1363), 392 (2009).

41) M. Mizuhata, A. Hosokawa, A. B. Béléké, S. Deki ; Chem. Lett., 38, (10), 972 (2009)

42) M. Mizuhata, A. Hosokawa, A. B. Béléké, S. Deki ; ECS Transactions, 19, (27), 41 (2009).

43) A. B. Béléké, M. Mizuhata ; J. Power. Sources, 195, 7669 (2010). 